\title{
The Influence of Leadership Style and Motivation on the Performance of Employees
}

\author{
Muhammad Andi Prayogi ${ }^{1 *}$, Muhammad Taufik Lesmana ${ }^{2}$
}

\author{
${ }^{1}$ University of Muhammadiyah Sumatera Utara \\ ${ }^{2}$ University of Muhammadiyah Sumatera Utara \\ *Corresponding author. Email: muhammadandi@umsu.ac.id
}

\begin{abstract}
The purpose of this study is to see how the influence of leadership style and motivation on the performance of employees at the Department of Employment Langkat. The approach in this study is associative by looking at their relationship or influence between independent variables and the dependent variable. Number of samples in this study was 70 respondents who are employees at the Department of Employment Langkat. Data processing techniques in this study using multiple linear regression. The results of this study partially leadership style significantly influence employee performance at the Department of Employment Langkat showed $t_{\text {count }}>t_{\text {table }}(2.450>1.666)$, partial motivation also significantly influence the performance of employees at the Department of Employment Langkat show $t_{\text {count }}>t_{\text {table }}(5.288$ $>$ 1.666). Simultaneously Style Leadership and Motivation positive and significant influence on employee performance at the Department of Employment Langkat, because $\mathrm{F}_{\text {count }}>\mathrm{F}_{\text {table }}(82.227>3.13)$. R-Square is 0.711 contributed $71.10 \%$, demonstrating the leadership style $\left(\mathrm{X}_{1}\right)$ and motivation $\left(\mathrm{X}_{2}\right)$ affect employee performance $(\mathrm{Y})$ at the Department of Employment Langkat, While the remaining $28.90 \%$ influenced by other variables not examined, such as work discipline, work environment, job stress, compensation, promotion, training and other variables.
\end{abstract}

Keywords: Leadership Style, Motivation and Employee Performance

\section{INTRODUCTION}

A reliable and skilled employee at this time is needed by every company. Employees are valuable assets owned by each company. In the era of the Industrial Revolution 4.0's technology is put forward. Each employee must be able to manage and implement technology systems that are around. A leader not only serves as a supervisor in a company but should be able to organize and manage existing resources in the company, the most important is how to adjust the existing human resources. Good communication between superiors and subordinates should be well maintained, so what is the purpose of the company can be reached. The leadership style of a boss has a very important role in the company, because a leader must be able to drive and motivate subordinates to work better. Around us a lot of looks a leader who works only commanding subordinates, as opposed to just come to the office sitting in the room waiting for the file to be signed. Things like this should never again happen. A leader must be able to protect his subordinates. If there is a problem that cannot be solved by a subordinate, then the role of a leader is needed here. The solution to the existing problems must be put forward, do not assume there is a problem of an employee who is a heavy burden. As opposed to just come to the office sitting in the room waiting for the file to be signed. Things like this should never again happen. A leader must be able to protect his subordinates. If there is a problem that cannot be solved by a subordinate, then the role of a leader is needed here. The solution to the existing problems must be put forward, do not assume there is problem of an employee who is a heavy burden. as opposed to just come to the office sitting in the room waiting for the file to be signed. Things like this should never again happen. A leader must be able to protect his subordinates. If there is a problem that cannot be solved by a subordinate, then the role of a leader is needed here. The solution to the existing problems must be put forward, do not assume there is a problem of an employee who is a heavy burden.

Leader or manager should be able to make an important decision regarding a problem not just simply analysing the existing problems. Leadership occurs as a result of a process of communication or interaction of individual leaders and the led. Because the leadership of a leader that has the right to full power over a group of individuals who lead. This research was conducted at the Department of Employment Langkat which aims to see 
how the style of leadership and motivation in improving the performance of employees at the Department of Employment Langkat. Power is an ability to influence the flow of energy and the funds available to achieve a goal clearly different from other destinations, a good leader can create awareness for its employees in meeting the expectations of a leader [1]. A leader can also affect the morale and performance of an employee. A good leader can motivate employees to be able to remove all the potential that exists in the employee himself which in turn will provide optimal results for companies [2]. Leadership theory has existed since the 20th century in which the development in leadership theory has always experienced obstacles in the development of the theory that is contrary to the transactional style or laissez-faire [3]. Leadership styles are a combination of every behavior in leadership [4]." A leader must be able to provide direction to subordinates so that what will be the goal can be realized. Leaders must care about all the changes that occur around, the process of adjustment to the work environment is very necessary in order to create a conducive environment and a leader must be able to provide good information to his subordinates [4]. The leadership style possessed by a person must be able to provide a positive influence on his subordinates. The leader must be able to direct subordinates to work better than before, so that a balance between function and goals is achieved [5].

Employee empowerment is very closely related to corporate organizational governance forming the characteristics of a harmonious internal relationship between leaders and subordinates so that later provides empirical evidence of the synergy of goals between leaders and employees within the company [6]. A leader must have a vision and mission so that the goals to be achieved can be realized. The role of the leader is very strategic in a company how to embrace each employee so they can work in accordance with what the company wants [7]. Style of leadership is a behaviour of a leader who used someone when they want to influence others [8]. Increasingly Leadership is understood to involve; persuasion and explanation as well as ability to identify, Affirm, and renew the values of the group the leader represents the. Managerial expertise, technical skills, cultural literacy and other relevant knowledge and skills are not sufficient virtues for the leaders Whose lives will be dedicated to public services [9]. The important thing that must be done by a leader is to motivate his employees so that all the rules that have been set are running properly. The success of a leader can be seen in the existence of a harmonious relationship between the employees, there is no mutual hostility, communication runs smoothly, there is no reproach between people, everything is well integrated [10].

Leadership is an activity to influence people so directed achieve the goal [11]. Leadership is a process of how to influence others so that the desired goals can be achieved [7],[8] stated that " At this time a leader cannot see directly what is being done by a subordinate due to changes in the work system, the distance that separates between a leader and his subordinates. The purpose of a leader is not only to motivate employees to work better, but a leader must also have the ability to influence subordinates in a positive direction so that what is the goal of the company can be achieved " [12]. There are six types of leadership, namely: 1) Type of autocratic leaders, 2) Type militarized, 3) Type of paternalistic, 4) Type charismatic, 5) Type Laissez faire, 6) democratic mode [13]. The benefits from the leadership style namely: a) Guiding, b) Guiding, c) Guiding, d) Establish, e) Giving or wake motivations of work, f) Driving organization [14]. Leadership style has an indicator or a determining factor, while the indicator of the style of leadership, namely: 1) Executive, 2) Lovers of development, 3) Autocratic good, and 4) bureaucrats. 5) Type of Laissez faire, 6) democratic mode employees [15]. This will impact on the performance of an employee. Problems in leadership are often the case that the absences of a leader who ignore not want to know the performance of employees. This will impact on the performance of an employee. Problems in leadership are often the case that the absences of a leader who ignore not want to know the performance of employees. This will impact on the performance of an employee.

Motivation is also an important thing in improving the performance of an employee. Many look around us a new employee is willing to start a job when a boss is around. There is no direct awareness will be a responsibility of the job in hand. The role of a leader is very important here, in order to create a high work ethic of subordinates. In the performance improvement of good communication between leaders and subordinates are indispensable. The communication aims to create a conducive working environment, there is no mutual reproach among one another. Words of praise can be too pronounced to subordinates of its good performance, because it can motivate an employee to work with passion and responsibility. Subordinates should also feel appreciated by his boss, is not only an award expected by an employee, but the attention of a leader can motivate them to work vigorously so that what the objectives of the company can be reached. "In Maslow's theory, motivation is a condition in which a person is physically in an effort to meet his needs Maslow's theory explains that a person works namely to meet his needs [16]. If the first life needs have been met, then someone will try to meet other needs [17]. A leader is expected to understand what the needs of his employees. Appreciation for an employee needs to be given so that the employee's enthusiasm for work and achieve what is the company's goals. Some employees work optimally with the expectation that they are given an award by the leader, but there are also some people who work as they are 
because they think everything can be resolved properly without great effort [18].

Companies, especially management, must be able to develop their employees so that they are skilled, have high productivity, so negative things can be removed from any bad prejudices that can result in decreased productivity, employee satisfaction [19]. Much of the recent academic research indicates that motivation is an important component in learning and achievement [20]. "An employee who has a high motivation is usually successful at work when compared to employees who are not motivated at work. Employees who be motivated, and then he will increase his ability to work, fix all the weaknesses he has by evaluating all the work he has done [21]. A good company organization should also evaluate its employees what are their weaknesses so that later the weaknesses can be overcome, one way is to conduct training for its employees so that later the employee can work better. Management must always motivate its employees not only employees who are still young, but employees who are already senior should also be motivated so that they are always productive in their work [22]. With this motivation it is expected that senior employees can work well if there is a change in the work environment. "Motivation is defined as an effort by someone how to be able to meet or achieve the goals set" [23]. While the element of motivation that: behavioural direction (direction of behaviour), the level of effort (level of effort), the persistence level (level of persistence) [24].

Divides motivational indicators consisting of: "1) Hard work, achievement of hard work achievement as a form of motivation to do work and responsibilities based or work hard in carrying out work, 2) Future orientation, based on broad insight has a real foresight and is applied at work, 3) a high level of ideals, the level of ideals and success is based on the amount of encouragement in oneself to achieve the maximum with the capabilities possessed, 4) Task orientation and task seriousness, Task orientation and task seriousness are based on understanding the meaning of the work carried out as well as possible with a maximum level of seriousness, 5) Efforts to progress, Efforts to progress are based on views that motivate themselves to always have ideas and ways that are better in carrying out work, 6) Perseverance works, Perseverance works d based on attitude and loyalty in carrying out work without having a sense of boredom to always work well, 7) Relationships with coworkers, colleagues who support each other will encourage employee motivation to work. Motivation will arise by itself where the better the relationship is given, 8 ) the use of time, the time used manifested by employees as well as possible as a high motivation at work" [25].

" Good planning is really needed in order to realize the vision, mission, goals and objectives that were set at first aimed at improving the performance of every employee in the company" [26]. "The performance of a set of behaviours that value employees who contribute either positively or negatively to the fulfilment of the organization's objectives [27]. "That the performance of the output produced by the functions or indicators of a job or a profession in a given time. Thus, the performance of employees can be concluded as a result that is achieved by a person in carrying out the work that has been given previously [28]. Indicator of employee performance that is: 1) Quality of work, 2) Quantity of work, 3) Toughness, 4) Attitude [29].

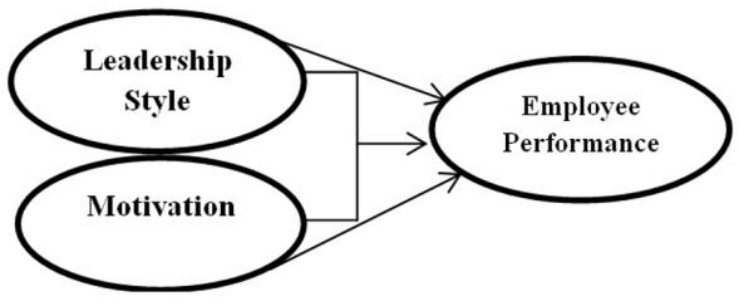

Fig. 1. Conceptual Framework

The hypothesis of the research conducted in this: Hypothesis 1: Partially style of leadership significantly influences employee performance, Hypothesis 2: Partially motivation significant effect on employee performance, and Hypothesis 3: Simultaneously styles of leadership and motivation have a significant effect on employee performance.

\section{METHODS}

The method used in this research is quantitative method, using saturated samples that are part of the population. The number of samples in this study was 70 respondents. The data in this study using multiple linear regressions with SPSS 22 as media calculations, by testing normality, heteroscedasticity, and multicollinearity of each variable studied.

\section{RESULTS AND DISCUSSION}

The results and discussion of this research can be seen in the table listed below:

Table 1. T-test results (partial)

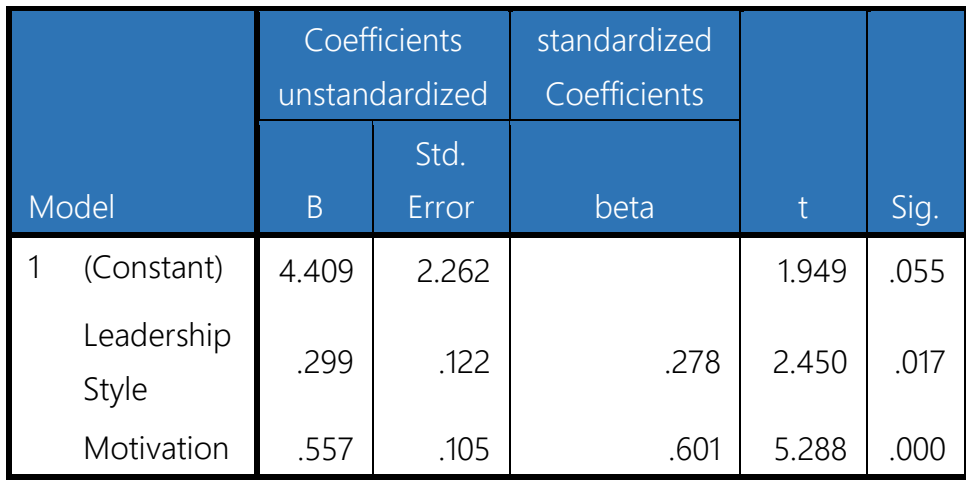

a. Dependent Variable: Employee Performance 
Regression analysis of the above equation is: $\mathrm{Y}=$ $4,409+0.299 X_{1}+0.557 X_{2}$, where $X_{1}$ (Leadership Style) $\mathrm{t}_{\text {count }}$ is worth 2.450 , where the value $\mathrm{t}_{\text {count }}>\mathrm{t}_{\text {table }}(2.450$ $>1.666)$ partially Leadership style positive and significant effect the performance of employees with a significant level of $0.017<0.05$, while $\mathrm{X}_{2}$ (Motivation) $\mathrm{t}$ count is worth 5.288, where the value $\mathrm{t}_{\text {count }}>\mathrm{t}$ table $(5.288$ $>1.666)$ partially motivation positive and significant effect on the performance of employees with a significant level of $0.000<0.05$, Thus the above calculation, the previous hypothesis can be accepted.

Table 2. Simultaneous Results (F-Test)

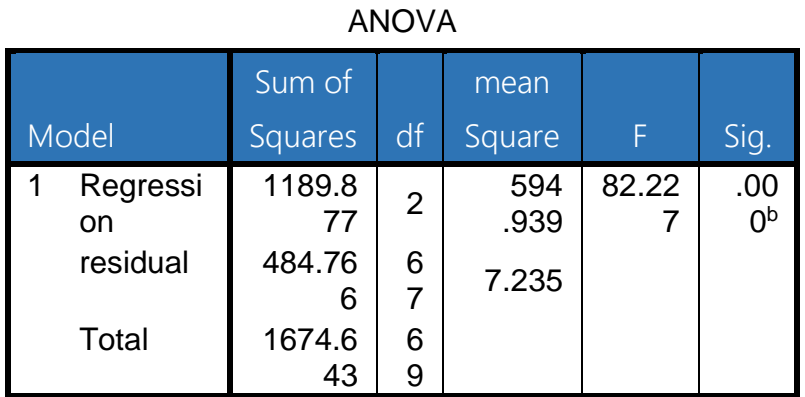

a. Dependent Variable: Employee Performance

b. Predictors: (Constant), Motivation, Leadership Style

From the table above shows the results of the calculation of the F test (ANOVA) F count value of 82.227, thus $F$ count $>F$ table $(82.227>3.13)$. Simultaneously variable style Leadership and Motivation positive and significant effect on the performance of employees at the Department of Employment Langkat, where the level of 0.000 significance level of $<0.05$.

Table 3. The Coefficient of Determination Result Model Summary

\begin{tabular}{|l|c|r|r|c|}
\hline Model & $\mathrm{R}$ & $\begin{array}{c}\mathrm{R} \\
\text { Square }\end{array}$ & $\begin{array}{c}\text { Adjusted R } \\
\text { Square }\end{array}$ & $\begin{array}{c}\text { Std. Error of } \\
\text { the Estimate }\end{array}$ \\
\hline 1 & $.843^{\mathrm{a}}$ & .711 & .702 & 2.68985 \\
a. Predictors: (Constant), Motivation, Leadership Style \\
\multicolumn{3}{|c|}{ Dependent Variable: Employee Performance } \\
\hline
\end{tabular}

From the table above shows that the value of R Square $\left(\mathrm{R}^{2}\right)$ total of 0.711 , or by $71.10 \%$. Value $71.10 \%$ mean variable employee performance $(\mathrm{Y})$ is determined by variable Leadership Style $\left(\mathrm{X}_{1}\right)$ and Motivation $\left(\mathrm{X}_{2}\right)$, while the remaining $28.90 \%$ influenced by variables not examined in this study, such as work discipline, work environment, job stress, compensation, promotion, training and other variables.

\section{CONCLUSIONS}

A leader in the company should be able to guide and protect his subordinates, a leader not only commanding subordinates to work, but it can provide solutions to existing problems. Good communication between the leaders and subordinates will create a comfortable working environment. The leadership must motivate their subordinates to work better with full awareness and responsibility for the work that has been given. Motivation starts from small things, for example giving a word of praise to subordinates on work performance was good, harmonious atmosphere can give the feel of a family in a corporate environment. If this can be created, then what is the purpose of the enterprise can be realized. The research result shows that the variable $X_{1}$ (Leadership Style) $t$ count is worth 2.450 , where the value $t_{\text {count }}>\mathrm{t}_{\text {table }}(2.450>1.666)$ partially Leadership style positive and significant effect on the performance of employees with a significant level of $0.017<0.05$, while $\mathrm{X} 2$ (Motivation) $\mathrm{t}$ is worth 5.288, where the value $\mathrm{t}$ count $>t$ table $(5.288>1.666)$ partially motivation positive and significant effect on the performance of employees with a significant level of $0.000<0.05$. The results of the calculation of the $\mathrm{F}$ test (ANOVA) $\mathrm{F}$ count value of 82.227 , thus $F$ count $>F$ table $(82.227>3.13)$. Simultaneously variable style Leadership and Motivation positive and significant effect on the performance of employees at the Department of Employment Langkat, where the level of a significant level of $0.000<0.05 \mathrm{R}$ Square $\left(\mathrm{R}^{2}\right)$ total of 0.711 , or by $71.10 \%$. Value $71.10 \%$ mean variable employee performance $(\mathrm{Y})$ is determined by variable Leadership Style $\left(\mathrm{X}_{1}\right)$ and Motivation $\left(\mathrm{X}_{2}\right)$, while the remaining $28.90 \%$ influenced by variables not examined in this study, such as work discipline, work environment, job stress, compensation, promotion, training and other variables.

\section{REFERENCES}

[1] Jamaludin, Pengaruh Gaya Kepemimpinan Terhadap Kinerja Karyawan Pada PT, Kaho IndahCitra Garment Jakarta, Journal of Applied Business Economic, Jakarta: Universitas Indraprasta PGRI, vol. 3 (3), 2017, pp. 161-169.

[2] F. Hardian, K. Rahardjo, M. S. Hakam, Pengaruh Gaya Kepemimpinan Terhadap Kinerja Karyawan (Studi Pada Karyawan Tetap Service Center Panasonic Surabaya), Jurnal Administrasi Bisnis, Malang: Universitas Brawijaya, 1 (1), 2015, pp. 17.

[3] R. Alonderiene, M. Majauskaite, Leadership style and job satisfaction in higher education institutions, International Journal of Educational Management, United Kingdom: Emerald Group Publishing Limit, vol. 30 (1), 2016, pp. 140-164. 
[4] J.P. Howell, D.L Costley, Understanding Behaviors for Effective Leadership, New Mexiko State University: Pearson Prentice Hall, 2006.

[5] C.I Fertman, J.A.V Linden, Character education for developing youth leadership, Education Digest, vol. 65(4), 199, pp. 11-16.

[6] L. R. Men, D. W. Stacks, The impact of leadership style and employee empowerment on perceived organizational reputation, Journal of Communication Management, United Kingdom: Emerald Group Publishing Limited, vol. 17 (2), 2013, pp. 171-192.

[7] S. T. Raharjo, D. Nafisah, Analisis Pengaruh Gaya Kepemimpinan Terhadap Kepuasan Kerja, Komitmen Organisasi dan Kinerja Karyawan (Studi Empiris Pada Departemen Agama Kabupaten Kendal dan Departemen Agama Kota Semarang), Jurnal Studi Manajemen \&, Organisasi, Semarang: Universitas Diponegoro, vol. 3 (2), 2006, pp. 69-81.

[8] A. Khairizah, I. Noor, A. Suprapto, Pengaruh Gaya kepemimpinan Terhadap Kinerja Karyawan (Studi Pada Karyawan di Perpustakaan Universitas Brawijaya Malang), Jurnal Administrasi Publik, Malang: Universitas Brawijaya, vol. 3 (7), 2010, pp. 1268-1272.

[9] I. N, A. S, H. N, Effect of Leadership Style on Employee Performance, Arabian Journal of Business Management Review, Brussels: Hilaris Publisher, vol. 5 (5), 2015, pp. 1-6.

[10] Mustaqim, The Influence of Leadership Styles and Motivation of Employees Job Satisfaction, International Journal of Economics and Finance, Canada: Canadian Center of Science and Education vol. 8 (10), 2016, pp. 176-183.

[11] W. Terry, Shared Leadership: The Essential Ingridients for Effective PLCs., 2000.

[12] J.L Gibson, Organisasi, Perilaku, Struktur dan Proses, Edisi ke-5, Jakarta: Penerbit Erlangga, 2000.

[13] S. Samsudin, Penentuan Penerimaan Remunerasi Dosen Dengan Rule Based Reasoning Lembaga Penelitian Dan Pengabdian Kepada Masyarakat (LP2M) Universitas Islam Negeri (UIN) Sumatera Utara Medan, Medan, 2018.

[14] K. Kartono, Pemimpin dan Kepemimpinan : Apakah Kepemimpinan itu Abnormal? , Jakarta : RajaGrafindo Persada, 2017.

[15] M. Thoha, Kepemimpinan dalam manajemen Jakarta: Raja Grafindo Persada, 2013.

[16] A. Risambessy, B. Swasto, A. Thoyib, E.S Astuti, Pengaruh Gaya Kepemimpinan Transformasional, Motivasi, Burnout Terhadap Kepuasan Kerja dan Kinerja Karyawan, Jurnal Aplikasi Manajemen, 2011, vol. 9 (3).

[17] J. M. Howell, B. J. Avolio, Transformational leadership, transactional leadership, locus of control, and support for innovations: key predictors of consolidated-business-unit performance, Journal of Applied Psychology, vol. 78 (6), 1993, pp. 891-903.

[18] S.P Robbins, Organizational behavior, PT Index, Jakarta: Gramedia Group, 2006.

[19] R. M Steers, L.W Porter, G. A Bigley, Models of leadership, In R. M. Steers, L. W. Porter, G. A. Bigley (Eds.), Motivation and Leadership at work, New York, McGraw-Hill, 1996.

[20] F. Guay, J. Chanal, C.F Ratelle, H.W Marsh, S. Larose, M. Boivin, Intrinsic, identified, and controlled types of motivation for school subjects in young elementary school children.

[21] K. U. Kalimullah, S. U. Farooq, M.I. Ullah, The relationship between rewards and employee motivation in commercial banks of Pakistan, Research Journal of International Studies, vol. 14 2010, pp.37-52.

[22] R. C. Stamov, G. Hertel, Older workers'motivation: Against the myth of general decline, Manage-ment Decision, vol. 48, 2010, pp.894-906.

[23] T. H. Handoko, Manajemen Edisi 2, Yogyakarta: BPFE, 2012.

[24] J.M. George, G.R Jones, Understanding and Managing and Organizational Behavior, Fourth Edition, New Jersey: Prentice Hall, 2005

[25] A. A. A. P. Mangkunegara, Human Resources Management, Bandung: Teen Rosdakarya, 2002.

[26] Moeheriono, Perencanaan, Aplikasi, dan Pengembangan Indikator Kinerja Utama (IKU) Bisnis dan Publik, Jakarta: PT Raja Grafindo Persada, 2012.

[27] Sunyoto, Burhanudin, Teori Perilaku Keorganisasian, Yogyakarta: Penerbit CAPS (Center of Academic Publishing Service), 2015.

[28] Wirawan, Evaluasi Kinerja Sumber Daya Manusia Teori Aplikasi dan Penelitian, Jakarta: Salemba Empat, 2009.

[29] Sudaryono, Metodologi Penelitian, Jakarta: PT Raja Grafindo Persada, 2017.

[30] O. I. Dobre, Employee motivation and organizational performance, Review of Applied Socio- Economic Research, Seattle: Semantic Scholar, vol. 5 (1), 2013, pp. 53-60.

[31] M. Rožman, S. Treven, V. Cancer, Motivation and satisfaction of employees in the workplace, Business Systems Research, UK: De Gruyter, vol. 8 (2), 2017, pp. 14-25.

[32] G. Panisoara, N. Duta, I. O. Panisoara, The Influence of Reasons Approving on Student Motivation for Learning, Procedia Social and Behavioral Science, UK: Elsevier, vol. 197, 2015, pp. 1215-1222.

[33] G. A. Yukl, Leadership in Organizations, $5^{\text {th }}$, New Jersey: Prentice-Hall, 2002. 
[34] A. Mangkunegara, Human resources management, Bandung: Teen Rosdakarya.British Journal of Educational Psychology, vol. 80 (4), 2010, pp. 711735 .

[35] M. S. P. Hasibuan, Human Resource Management, Jakarta: Earth Literacy, 2005.

[36] J. Chanal, C. F. Ratelle, H. W. Marsh, S. Larose, M. Boivin, Intrinsic, identified, and controlled types of motivation for school subjects in young elementary school children, British Journal of Educational Psychology, UK: The British Psychological Society, vol. 80(4), 2010, pp. 711-735.
[37] J. Howell, B. Avolio, Transformational leadership, transactional leadership, locus of control, and support for innovations: key predictors of consolidated-business-unit performance, Journal of Applied Psychology, Washington: American Psychological Association, vol. 78 (6), 1993 891903.

[38] S. P. Robbins, Organizational behavior, PT Index, Jakarta: Gramedia Group, 2006.

[39] L. Porter, G. Bigley, L. W. Porter, A. Bigley, Motivation and Leadership at work, $6^{\text {th }}$ ed, New York: McGraw-Hill, 1996. 